\title{
The Marine Knowledge Exchange Network: insights from an innovative regional-to-national scale academic-led knowledge-to-impact network and recommendations for future initiatives.
}

M.T. Johnson ${ }^{\mathrm{a}, \mathrm{b}, \mathrm{c} *}$, G.A. Bayliss-Brown ${ }^{\mathrm{d}}$, L.J. Johnson ${ }^{\mathrm{e}}$, V. Danino ${ }^{\mathrm{f}}$, S. Day ${ }^{\mathrm{a}}$, I.

Dunnett $^{\mathrm{g}}$, J. Forster ${ }^{\mathrm{h}}$, , I. Lorenzoni ${ }^{\mathrm{a}}$, K. Kennedy ${ }^{\mathrm{e}}$, G. Malin ${ }^{\mathrm{a}}$, K. Moore ${ }^{\mathrm{i}}$, P. Moore Fuller $^{\mathrm{j}}$, M. Walton ${ }^{\mathrm{a}, \mathrm{e}}, \mathrm{T}$. Tolhurst ${ }^{\mathrm{a}}$

${ }^{a}$ School of Environmental Sciences, University of East Anglia, Norwich, UK; ${ }^{b}$ Centre for Environment, Fisheries and Aquaculture Sciences, Lowestoft, UK; ${ }^{c}$ Bantry Marine Research Station, Gearhies, Co. Cork, Ireland; ' ${ }^{A q u a T T, ~ U n i t ~ 3, ~ O l y m p i c ~ H o u s e, ~ P l e a s a n t s ~ S t r e e t, ~ D u b l i n ~}$ 8, Ireland; ${ }^{e}$ Blue Ltd., Norwich, UK, ${ }^{f}$ Anglian Water Centre for Water Studies, Norwich, UK; ${ }^{g f}$ NewAnglia Local Enterprise Partnership, Ipswich, UK; ${ }^{h}$ School of International Development, University of East Anglia, Norwich, UK; ${ }^{i}$ Environment Agency, Ipswich, UK, ${ }^{j}$ Infohackit, Norwich, UK

*corresponding author doctor.m.johnson@gmail.com 


\title{
The Marine Knowledge Exchange Network: insights from an innovative regional-to-national scale academic-led knowledge-to-impact network and recommendations for future initiatives.
}

\author{
This paper provides an overview of the approach taken by the Marine Knowledge \\ Exchange Network (M-KEN) and an assessment of its activities in valorising and \\ generating impact from research. M-KEN was formed in 2014 in response to a call for \\ projects to accelerate impact generated from environmental research in the United \\ Kingdom (UK). M-KEN was university-led and focussed in the eastern region of the UK \\ but its approach to fostering impact has had international reach. Over the course of its first \\ five years, M-KEN has leveraged substantial additional funding; spawned numerous spin- \\ off projects; influenced policy and practice; and supported a range of marine research \\ projects in the delivery of their research to stakeholders.
}

This paper demonstrates that the reach of M-KEN has been international and has led to substantial ripples of activity radiating out from the core activity of the network. We reflect on the strengths and weaknesses of the approach taken by M-KEN in the context of key research questions around Knowledge Exchange . Finally, we propose recommendations for endeavours from regional to global scale that wish to develop impact from a portfolio of research.

Keywords: research impact, knowledge exchange, marine science, coastal science, social science, valorisation

\section{Introduction}

Given the current environmental crises of climate change, biodiversity loss, pollution and food security, creating a space for research to be shared across disciplines and incorporating perspectives from a range of stakeholders to provide essential solutions for people and the planet has never been more important. Visbeck (2018), in his commentary on the forthcoming UN Decade of Ocean Science for Sustainable Development (2021-2030), makes the case that ocean science research is key to a sustainable future but to meet the challenges that the ocean faces, 
more solutions-oriented research is needed to "develop and flesh out sustainable blue-green growth agendas and link it to efforts in ecosystem protection". He implies the need for disruptive change; both in the way that scientific research is designed and how it is used to deliver real progress in ocean sustainability.

Knowledge exchange (KE) is an essential step in realising the benefits from new and wideranging knowledge, the academic study of which is relatively new (Fazey et al., 2013, Nguyen et al., 2016). This paper presents the approach taken by the Marine Knowledge Exchange Network (M-KEN), a regionally-focussed initiative to increase the impact of coastal and marine research in the east of England, principally by providing a platform for, and facilitating, KE. An account of the activities to date is presented in the online supplemental material and is summarised here along with an assessment of its activities for valorising and generating tangible impact from research. This is presented as a case study, in order to contribute a set of insights into some of the key research questions and issues identified in the emerging KE literature, reflecting on the strengths and weaknesses of the approach taken by M-KEN. Within this context, we propose recommendations for future initiatives aiming to contribute to the global effort to use research knowledge to further the goals of ocean sustainability.

M-KEN, led by environmental scientists, was not rooted in an academic study of impact or KE. Rather it was undertaken with the spirit of exploration: engaging with research users and together co-creating translation activities and materials in an innovative, entrepreneurial spirit. Therefore much of the analysis here is based on a post hoc study of the context and outcomes of M-KEN. 


\section{Knowledge Exchange and the 'impact agenda'}

Fazey et al., 2014 (and references therein) argue that the traditional 'positivist' viewpoint of academic researchers as the source of knowledge in a one-way process of knowledge delivery are being supplanted by "activities that include multi-way interaction and co-production of knowledge between researchers, decision makers and other beneficiaries of science" (Fazey et al., 2014). Key issues around the role of, and need for, knowledge brokers, mediation spheres, or 'boundary spanning organisations and individuals' in successful KE emerge from the recent literature (Cvitanovic et al. 2015, Cvitanovic et al. 2017, Cook et al. 2013a, Nguyen et al. 2016, Bednarek et al. 2018). Amongst a wide range of future KE research questions arising (e.g. Fazey et al., 2013), important questions have been raised by numerous authors about institutional barriers and disincentives to KE initiatives and activities (Cvitanovic et al. 2015, Nguyen et al. 2016, Bednarek et al. 2018, Fabian et al. 2019) and the need for further study of the influence of KE context (for example the types of institutions and job roles of the individuals involved in a particular piece of KE) and external forces on knowledge mobilization outcomes (Nguyen et al. 2016 and Fazey et al. 2013). Methods of evaluation of the success of KE activities is also a key area of interest in KE studies (e.g. Fazey et al., 2014).

Demonstrating the 'impactfulness' of research has become increasingly important for individual academics, projects and academic institutions over the last decade (Fazey et al., 2014., Pearce and Evans, 2018). This has been driven by funding pressure, government and funding agencies' requirements to justify public spending and the growing requirements for greater accountability in higher education. In particular, the UK's public sector research system is recognised as the global leader in implementing a formalised 'impact agenda' (Hill, 2016; Morgan-Jones et al., 2017).

There is no commonly agreed definition of research impact, although numerous authors cite the definition used in the Research Excellence Framework (REF) 2014 research evaluation 
exercise in the UK, the first such evaluation to consider impact as well as academic merit (Morgan-Jones, et al., 2017):

"An effect on, change or benefit to the economy, society, culture, public policy or services, health, the environment or quality of life, beyond academia"

UK research councils (who distribute the majority of UK government funding for academic research) have, since around 2010, required an 'impact statement' - describing the likely impacts of the proposed research beyond academia - and a 'pathways to impact' document - outlining the plan for activities to maximise this impact to accompany grant applications to most funding calls. Environmental science has not typically had strong links to commercial research-users and so many proposals have called on support from a small number of policy stakeholders, risking 'stakeholder fatigue' (e.g. Bracken et al., 2014). Arguably, some small-scale, primary research proposals are not really appropriate for this level of direct engagement with stakeholders as the likely outcomes are not directly or immediately of interest to stakeholders outside of research (although typically contributing 'building blocks' towards a body of knowledge that is of great interest and value). Furthermore individual research projects in the UK are typically required to develop 'piecemeal' individual impact plans with key stakeholders and rely on the abilities and resources of an individual or a small research team, whom may not have expertise in or motivation to maximise knowledge mobilisation (e.g. Perez Vico et al., 2015).

The risks associated with this 'individualising' of impact activities is compounded by attitudes towards impact activity as a box-ticking exercise which detracts from key academic activities (e.g. Pearce and Evans, 2018; Chubb and Watermeyer, 2017; Smith and Stewart, 2017). The risk of over-enhancing claims of impact achievements, the difficulty of tracing the impact that a particular piece of research has and the dedication of scarce resources (both time and money) to this tracing activity are identified as major concerns in numerous studies of academics' attitudes to impact activities (e.g. Pearce and Evans, 2018; Chubb and Watermeyer, 
2017). In spite of such concerns about the impact agenda, the desire for societal or environmental good to come from research is an attitude generally shared by the majority of academics and is rather separate from the impact reporting activities driven by REF and 'pathways to impact' requirement of research funding in the UK (Pearce and Evans, 2018).

Co-design and co-production of research outcomes, KE, and communication activities, and stakeholder engagement are all key steps that may enhance the potential impact of research (Armstrong and Alsop, 2010; COLUMBUS, 2018a; Porter et al., 2019a, Reed et al. 2014, Cvitanovic et al. 2015), but they are not in themselves indicators of impact according to most definitions (Penfield et al, 2014), nor do they guarantee impact for any individual piece of research. A number of case studies of KE activities were produced by the COLUMBUS project (COLUMBUS 2018b), which illustrate that the eventual route from a piece of research to its impact can be complicated, and presents a narrative of road blocks, serendipity and persistence (COLUMBUS, 2018c; Porter et al., 2019b). If significant impact does result it may occur some time after subsequent research is conducted, or after external changes (e.g. to policy, technology) allow the knowledge to be taken up (e.g. Penfield et al., 2014, Manville et al., 2015). For these reasons it could be argued that the linear view of impact (Fig 1, analogous to the positivist view of $\mathrm{KE}$ ) does not properly represent the underlying nature of how knowledge generated through research truly leads to impact and may not be the best way to design a system for maximising impact from a portfolio of research (at scales from individual research group to international research community).

“...research impact frameworks [such as the Research Excellence Framework] take a more or less linear view of impact (dollars in, grants awarded, papers published, findings translated, impact achieved) and generally focus on a limited range of predefined impact metrics such as deaths avoided or improved health status. Such "logic models" have their place, but they are particularly unfit for purpose for assessing the interactions, negotiations, and activities of an unstable and organically evolving research system in which the chain of causation for any particular outcome is diffuse and contested" (Greenhalgh et al, 2016). 
The concept of research valorisation - the processes and actions which create value and build impact from research activity - is useful in providing alternative ways to assess impact generation processes (DANDELION, 2018). Van Drooge, et al. (2013) state that

\footnotetext{
"Valorisation is the process of creating value from knowledge by making knowledge suitable and/or available for economic and/or societal use and translating that knowledge into competitive products, services, processes and entrepreneurial activity. Knowledge valorisation is a complex and iterative process in which interaction between knowledge institutions, business and NGOs - at all stages of knowledge development - is important."
}

With valorisation comes a recognition that value is added to knowledge at all stages of progress towards an eventual impact, not just at the point of achieving the intended impact itself (e.g. Hill, 2016, COLUMBUS, 2018a, DANDELION, 2018). This process-based assessment of impact lends itself to recognition of early stage impact development and allows recognition of activities that are more broadly developmental as well as tangible impact outcomes (e.g. commercialisation of a product, key policy change, behaviour change).

DANDELION (2018) propose draft 'Impact Readiness Levels' (IRLs) for research (Table 1) based on the 'Societal Readiness Levels' defined by Innovation Fund Denmark (2019) for social sciences and health (SSH) research. As noted by DANDELION (2018): "IRL should be not understood as a measure of factual, delivered impact, but as a probability or maturity indicator of SSH research to deliver impact". The authors of these readiness levels note that SSH research commonly struggles to demonstrate direct and tangible impact outcomes and therefore argue for valorisation of all stages of the impact process. This issue is arguably common to other forms of research including marine and coastal research and therefore the approach of valuing activities against these readiness levels is a useful way of acknowledging impact more holistically. Societal readiness levels as an indicator for impact have already been applied to a marine research project (COLUMBUS 2018c). 
The success of impact initiatives, and the realisation of societal benefit from research is necessarily grounded in building relationships of trust and identification of mutual benefits between users of research. Ozanne et al. (2016) argue that "persistent and iterative interactions among all stakeholders, instead of opportunistic, one-shot deals, are key" and identify network building outside academia as a key type transaction type that is required to generate research uptake and impact. Armstrong and Alsop (2010) identify that the following are vital components of impact generation: 1) Established relationships and networks with user communities; 2) Involving users at all stages of research - not as subjects, but as project partners; 3) Wellplanned (and properly resourced) user engagement and KE strategies; 4) Portfolios of research activity that build reputation with research users; 5) Good infrastructure and management support; and, 6) Where appropriate, the involvement of intermediaries and knowledge brokers as translators, amplifiers, and network providers. Thinking along these lines led us to conceptualise a cyclic (as opposed to linear), network-based model of impact generation (Fig 1) and this represents our thinking and motivation at the outset of the M-KEN project in 2014.

\section{Marine Knowledge Exchange Network 2014-2018}

M-KEN was conceived and founded in April 2014 by a cross-sector group with an interest in marine and coastal science in East Anglia (a region in the East of England). It was intended as a vehicle for building a critical mass in the region to drive forward the wider national / international research agenda; translate knowledge from research into policy and practice; and to raise the region's reputation for leadership in marine and coastal science and management. It sought to achieve this by building a network of invested members representing multiple sectors (business, policy, local government, NGO, practitioners, charities etc.) through a series of 'meetups', seminars, workshops and conferences and through digital media (websites, videos, social media platforms, etc). This 'social' network would then go on to generate new opportunities for translation of existing and ongoing research as well as generating new, truly co- 
designed research projects as the network evolved. Further details of the timeline, development, funding and activities of M-KEN are provided in the supplemental material.

\section{Vision}

M-KEN's aim was to move away from 'linear impact' as well as piece-meal impact generation; to instigate a broad network of engaged stakeholders in the portfolio of coastal and marine research activity occurring in the region and beyond; as well as stimulate project-specific dialogue around the coastal and marine sectors in the region. This was in recognition that building a 'critical mass' of engaged stakeholders (including researchers) would underpin future impact generation through 'cross-pollination' of ideas and opportunities and initiation of an impact "cycle", via the network-based impact model (Figure 1). Taking inspiration from ideas of open innovation networks from start-up culture (e.g. Spender et al., 2017) it was reasoned that an open KE network would foster the entrepreneurial spirit of researchers and research users. It would also provide a platform to stimulate disruptive approaches to KE and discovery of impact opportunities. A broad network would also avoid stakeholder fatigue and multiplication of engagement (i.e. multiple projects interacting separately with the same stakeholders over the same or similar issues; Doremus, 2017) by providing knowledge brokerage services.

Furthermore, by providing an open forum in which mutually beneficial activities could be identified and performed, it was asserted that the process of KE would become emergent rather than requiring 'carrots' or 'sticks' (beyond those already in place from research funders). It would stem not only from the results of specific research projects but also the broader expertise of the group, both in terms of research knowledge but also expertise of practice, policy-making and innovative business thinking, particularly from start-ups and small-to-medium-sized enterprises (SMEs). This would lead to real co-production of new research, informed by the needs of the research users. 
Visualisation of scientific data, methods and concepts has been recognised as an increasingly important component of the research-impact cycle (e.g. McInerny et al. 2014). A unique aspect of the M-KEN vision among the impact acceleration projects occurring at that time, was to put visual research communication to the fore (including data visualisations, infographics, posters, videos, live-presentations and displays - see Fig S1, supplemental material). From the outset of M-KEN, budget was dedicated to the development of visual communication tools as a key part of the research translation effort and to build capacity in the regional graphic design sector to deliver science-rich outputs.

Overall, M-KEN raised funds in direct support of its activities in excess of $£ 300 \mathrm{k}$ in four years, and these funds have been used to develop impact activities across a portfolio of coastal and marine research as well as reinvestment into network building and communications. A significant amount of cost resource was also dedicated to securing 'next-level' funding to ensure the longer-term stability and growth of the network which, despite some 'near misses', was unsuccessful.

\section{Influence and Reach}

M-KEN's activities have had influence in a variety of ways. A number of new projects and activities can be considered directly linked to, or resulting from, M-KEN activity. These range from projects proposed and won by M-KEN; new initiatives based on the networking method and network itself developed by M-KEN and its members; research projects directly supported by M-KEN; and, broader policy-influencing and scientific synthesis activities supported by MKEN. Selected significant and closely linked projects are briefly outlined in Table S2 (supplemental information).

In addition to projects that M-KEN has influenced, it has valorised and delivered impactbuilding activities for specific research outputs and for the broad portfolio of marine and coastal 
research in the region (see following section for an assessment of its impact) and these activities have in turn influenced organisations such as Defra (UK Government's Department for Environment, Food and Rural Affairs). It has built a strong network of links within and between researchers and research users in the region of East Anglia and promoted mutual understanding of the needs and capabilities of each group. The approach taken by M-KEN has influenced other $\mathrm{KE}$ and impact activities nationally and internationally, partly through the dissemination of the M-KEN approach to other groups but also through the subsequent or additional activities of MKEN core team members as their personal networks and activities developed. These 'influences' of M-KEN are multi-faceted, numerous and difficult to present briefly. Figure 2 summarises these in a broad manner.

\section{M-KEN's outputs, influences and outcomes and assessment of impact}

The evaluation of KE networks tends to be inductive, using mixed methods and requiring longer term evaluations when compared to positivist KE activities (Fazey et al., 2014). We have attempted to formalise the approach for M-KEN by assessment of the impact readiness level (IRL) of selected outputs, specific influences and outcomes (Table 2). The IRL assessment was conducted by the authors of this paper, based on their knowledge of the activities in question compared against the IRL criteria from DANDELION (2018) (Table 1) as objectively as possible. The IRLs from DANDELION (2018) are interpreted here for the marine and coastal research portfolio that M-KEN represented (rather than for specific research projects or findings).

This analysis demonstrates that M-KEN has contributed significantly to the first half of the ‘impact chain' (IRLs 1-3) and in some cases moved towards or into the second half (IRL 4-6). This highlights (and our experience confirms) that M-KEN has taken a whole portfolio of 
research and a network of researchers, research users and stakeholders to IRL 3 and beyond - i.e. that the network and research base was primed and ready to develop individual research translation and impact activities as appropriate to the specific research output and needs of the stakeholder community. In this way, though unquantifiable, the value added by such an activity is significant. We argue that the cost of reaching this stage (£300k) is small compared to the money invested by funders into developing the body of knowledge and expertise represented by the researchers and their projects, which stretches into the tens of millions of pounds when considering just ten years of direct research funding on marine and coastal science by NERC to a single University. Even taking a highly conservative figure of $£ 10 \mathrm{M}$, the investment in M-KEN represents only about $3 \%$ of the investment in the research it represents.

M-KEN has therefore had tangible impact through valorisation of research. Furthermore, significant impact outcomes are anticipated, in time, from the Blue Futures project (i.e. a change in practice, policy or application of its methodology to other regions). It is argued here that MKEN's largest impact has been on the adoption of approaches to KE and impact generation activities in marine, coastal and environmental sciences. Ideas from M-KEN have propagated internationally. As an example, one individual within the original M-KEN team now specialises in KE for marine research, including holding a leadership role in the COLUMBUS project, which was recognised as the European Commission's flagship project for 'Knowledge Transfer for Blue Growth', and Future Earth's Ocean Knowledge Action Network Working Group on Knowledge Mobilization. Other members of the M-KEN core team have gone on to work in consultancy on research impact and run a research centre focussed on bilateral interactions between a university and a large company.

A stakeholder relationship management system (SRM) was developed by and for MKEN. This (relational database) system allows the tracking of all levels and types of stakeholder engagement (logging details such as which M-KEN subscribers have participated in particular 
events). Used appropriately, this provides a powerful tool to target stakeholder groups for specific projects or purposes (for example identifying all stakeholders who have participated in a relevant event to or otherwise demonstrated an interest in a particular topic area). This system has been replicated for and used by the impact programmes for two NERC-funded Doctoral Training Partnerships. The regular and appropriate maintenance of such a stakeholder database potentially provides a lasting legacy of KE activities generated by a network such as M-KEN.

One notable outcome from collaboration between professional graphics designers was that researchers were keen to develop their own design skills, as part of a growing appetite for professional skills in science communication. Following a large training event with EnvEast Doctoral Training Partnership (University of of East Anglia, University of Kent, University of Essex and others), innovation funding was secured to develop a national training programme with five Doctoral Training Partnerships funded by the Natural Environment Research Council (NERC). To date, Infohackit (having successfully spun out as an SME) have run training events with over twenty UK universities. Hundreds of doctoral students have now improved their visual communication skills in workshops covering infographics, posters, visual abstracts and animation. More than 50 professional graphic designers have gained new experience of working with researchers. Developers of creative software (e.g. Serif Publishing) are now engaged in science communications and are exploring for the first time the use of their products by researchers. The Infohackit workshop methodology is now being adopted by the European Commission (2020) in its PESETA IV project, to communicate the impacts of climate change. The following important observations can be drawn upon MKEN development and activities:

- Prior to the creation of M-KEN, in spite of good existing individual-level relationships between researchers (mostly senior faculty) and regional stakeholders in policy, local government, commercial and NGO sectors, the level of knowledge about the broader 
portfolio of activities across the research community and research user 'divide' was very poor. An important valorisation step for M-KEN was 'knowledge and impact discovery' i.e. starting to increase knowledge in research users about what research expertise there was in the region and knowledge across the network about what research-user needs were and where there were opportunities to make a difference. This 'discovery' activity corresponds to IRL 1 in the DANDELION scale, but we found this early step to be one of the greatest 'accelerators' of progress towards impact and the networking approach added great value here;

- M-KEN's contribution was not solely in research knowledge valorisation. New partnerships and relationships developed in the stakeholder community through the open discussion, connectivity and cross-pollination of ideas that M-KEN and 'spin-off' activities fostered. For some it created new career paths and opportunities;

- It also built capacity across the research and research-user communities in the ability to interact beyond their normal professional boundaries with those from other sectors and to recognise that this garnered mutual benefit (both directly and in terms of social capital).

\section{Benefits and challenges}

We have shown that M-KEN added value to the research and stakeholder communities in its region (and beyond) and has made substantial progress towards 'making a difference' (i.e. having tangible societal and/or economic impact) through its activities. In this section, we reflect on the benefits and challenges from the perspective of the academics involved in leading the network and also consider the question of whether academic leadership (or university hosting and support) are beneficial or appropriate for such a network. 
Table 3 presents our summary of the benefits and risks to actors in a university-led knowledge network, based on our experiences with M-KEN. Our experience suggests that MKEN has been largely beneficial for all individuals (inside and outside of academia) involved; facilitating knowledge and impact discovery, broadening professional networks, providing new insights, increasing visibility and opening new opportunities. Research and stakeholder engagement practice has been significantly changed within the university over the timeframe of M-KEN; with much broader and more open relationships between the university and other stakeholder- and partner-organisations, and significant additional funding for 'relationship management'. However, no direct connection between M-KEN and these changes can be evidenced and it may be that both M-KEN and these institutional changes represent parallel activities in response to changing norms in the university research sector.

There have been significant structural challenges with M-KEN, many of which relate to its constitution as a 'project' within an academic institution and the need to demonstrate success over relatively short timescales:

- The motivation for M-KEN was to develop a network to deliver truly co-designed research to meet stakeholder and societal needs and therefore the 'spin-up' time is necessarily on the order of five to ten years until these new activities 'bear fruit' in terms of impact. Therefore, much of the benefit is not realised in the timescale of the types of funding available to support such activities;

- It does not 'fit the mould' - trying to do something innovative and different within a tightly controlled financial environment such as a university leads to significant challenges and large time investment in trying to solve administrative and financial problems. In particular, running an initiative that brings in a diverse range of funding streams and incomes in a strictly not-for-profit, publicly funded environment poses particular challenges; 
- Securing ongoing financial support is an existential challenge to the initiative. Academic leads have responsibility for ensuring financial viability and presenting business cases to funders and are involved in large numbers of grant proposals written in pursuit of impact for the common good rather than furthering individual research and impact activity;

- Communications and events can be a very large resource burden. The time-intensive job of overseeing communications, organising and/or participating in network events and promoting the network at conferences and meetings is essential to the success and longevity of initiatives such as M-KEN and falls to the core team of academics leading the network, unless resources can be secured for support staff. The periods where MKEN made most headway were those when event management and communications activities in support of the network were outsourced to contracted delivery partners or supported by administrative staff within the university (both of which had resource implications directly for M-KEN);

- It was particularly difficult for M-KEN and its champions to find time for the proper and extensive engagement with many academic peers within the institution, whose support is ultimately essential for long-term success of the endeavour.

The above points speak to a huge opportunity cost in properly and fully immersing oneself in the leadership of such a network. Ultimately, for an academic, it is not core business (even if ensuring impact for one's own research activity is) and career or lifestyle challenges are necessary to ensure the success of the initiative. This has proved a very real challenge for the academic directors of M-KEN, who have constantly juggled this very time-intensive 'edge of desk' project with core academic activities.

The above challenges and more broadly being reliant on periodic, uncertain or unreliable funding streams to maintain the core network at a level necessary to sustain activity is a significant challenge. Such a challenge threatens the long-term viability of any network 
particularly those functioning on a regional scale. Being part of a larger umbrella organisation supporting similar activities on a national or larger scale (e.g. European project or initiative) would be likely to greatly increase the viability of such an activity.

The challenge of communications is borne out in a consultant-led, independent internal review of M-KEN activities 2014-2018, in which the views of stakeholders external and internal (to the host university) were captured in a series of interviews. These highlighted differing views in the network, with M-KEN being generally viewed more favourably and having greater value attached to it by external vs internal stakeholders.

\footnotetext{
"There is a marked difference between how M-KEN is viewed externally to UEA and internally. For some of the primary external M-KEN stakeholders, it is seen as a real conduit for successfully penetrating and benefiting from the work that is undertaken at UEA; with the university seen as a significant repository of knowledge...' [which] '...some believe' ... 'to be impenetrable and fragmented from the outside. Perhaps in relation to this, it is important to reflect upon to what degree a university has a responsibility to its stakeholder community to be open and accessible? Internally, there is also a difference in how M-KEN is viewed between different UEA stakeholders. As would be expected, those forming the immediate M-KEN team see it as of potentially huge value...' 'However, for others M-KEN appears to be viewed as both disjointed and peripheral to core academic work. This is perhaps partially attributable to the 'classic academic' dichotomy, which often arises relating to what degree research direction should or should not be 'customer' led? Aligned, with this also, is variation across the internal stakeholder community pertaining to exactly how much research impact M-KEN has had, and also what such impact actually looks like on the ground?" Blue Ltd. 2018
}

Huggins et al. (2008) investigate the role of universities as leaders of regional knowledge networks (in the context of technological, highly-commercializable research). They conclude that the onus placed on universities to become bases of commercializable knowledge in their regions is probably too heavy and unlikely to succeed. Our observation is that in less commercializable research there is significant benefit to institutions being at the centre of a knowledge network (thus being able to benefit from relatively rare opportunities to drive impact). This means, 
however, that university leadership of the network risks significant bias in impact towards the research portfolio of that university. Whilst M-KEN was run as an open initiative with members of other academic institutions welcomed to meetings and invited to join in KE opportunities, it is inevitable that at some level self-interest would or did lead to bias. Certainly, in the initial stated aims of M-KEN (admittedly framed for the benefit of trying to win university support), promotion of the university's research portfolio and, by inference, competitive advantage for future funding were key objectives for the initiative (Table S1). We, therefore, reflect that an independent organisation would be better placed to manage the associated funds, run and coordinate a network, especially at a national or international scale, where the university/ies involved in leadership would be disproportionately represented relative to its/their normal geographic 'reach'.

\section{Challenges in the UK setting}

In spite of the strong drive towards generating impact from UK research, the sustainability of networks such as M-KEN, which looked mainly to research-based funding to support its activities, is limited. In fact, M-KEN's peak period of activity coincided with the period of initial impact accelerator funding from UK research councils and these sources, plus support from the university's HEIF (Higher Education Innovation Fund (HEIF) allocation. These sources provided significant funding for set-up and operation, but also expected M-KEN to work toward a self-sustaining business model in a relatively short time. This development of a 'business concern' became a particular challenge for operating M-KEN within a publicly funded context and various business models were considered.A membership model was inverstigated but was not implemented due to a) questions of how many organisations would subscribe and b) concerns over the additional pressure on the M-KEN team of delivery to fee-paying members. The most successful income model was that of offering impact services to research projects, whereby MKEN would assist in the development of the impact component of grant proposals in return for 
being costed in to deliver impact development services through its events, publications, graphic design capability and network. As well as providing a resource to maintain M-KEN's activities, the 'pathways to impact' in proposals that cited M-KEN were evaluated positively at the review stage, suggesting that funders and evaluators recognised the benefit of the network with regard to impact development.

As the UK higher education sector prepares for a Knowledge Exchange Framework (KEF; UKRI, 2020) to complement REF and the Teaching Excellence Framework (TEF), there may be more opportunity to encourage (multi-)university support for domain-specific knowledge exchange KE networks to drive forward $\mathrm{KE}$ and impact from research.

The overlapping roles and interests of industry-led clusters, umbrella organisations and networks (e.g. MaritimeUK http://maritimeuk.ork) with academic-led KE or impact networks is also an issue for consideration in the UK setting. Having too many networks, clusters and organisations is inefficient and ineffective, but the needs of different stakeholders can be very different so a 'one size fits all' approach may not be appropriate.

\section{Research insights for knowledge exchange}

The lessons learned through our involvement in M-KEN can feed usefully into the discussion of key research questions around $\mathrm{KE}$ and provide input to some core concepts and frameworks proposed in the KE literature. Table 4 presents a summary of the observations, questions and concepts arising in the literature, which we have grouped into seven core topics and offer our assessment of these core topics in Table 4 on the basis of the information presented above. This presents an accessible basis for evaluation of M-KEN's findings for future study of KE activities, and we summarise the insights M-KEN brings to these core topics below.

1) Integration of knowledge exchange in the design, development and delivery of research projects. We suggest that research impact and knowledge exchange can be facilitated through a long-term, multi-stakeholder approach. M-KEN ignited and fostered a plethora of cross-sectoral stakeholder 
relationships to inform and influence the regional marine research agenda. These relationships continue to facilitate dialogue and collaborations across the knowledge-action interface.

2) Development and utilisation of a framework for knowledge exchange activity.

M-KEN operated as a semi-independent mediating organisation between knowledge and its end-users. Our experience suggests that whilst the existence of such an organisation is certainly effective, the ability to maximise delivery of knowledge exchange is potentially impeded through direct academic leadership, due to the multiple foci of the academic role and in particular the need to progress one's own research agenda rather than a broader portfolio of interest to the network.

3) Utilising dedicated knowledge brokers to facilitate multi-stakeholder knowledge exchange. As M-KEN developed the members of the network developed multiple roles. Depending on the context, stakeholders from any sector (research, practice, policy, business etc) could assume roles of knowledge originators, brokers or users. This development of the network led to the opportunities for truly interdisciplinary research, knowledge production and impact.

4) Synthesis of research outcomes to provide focused and effective knowledge exchange outputs. We suggest the regional and topical focus of M-KEN generated stakeholder interest and engagement along with a sense of responsibility and ownership from the outset. The use of infographics to visually communicate research findings was particularly effective with busy research users.

5) Long-term assessment and monitoring of knowledge exchange activities. The M-KEN model of a domain-specific knowledge exchange network provides an opportunity to facilitate knowledge exchange well beyond the funding of a particular research project. Cross network collaboration can develop and secure funding for innovation, knowledge exchange and research activities, as well as building capacity to deliver services such as infographics noted in point 4 above.

6) Incentivising and valuing knowledge exchange activities, particularly within a research context. Our experience mirrors that in the literature and ultimately the full potential of M-KEN was not realised due to the time, budgetary and administrative constraints of the academic roles of the M-KEN leads. In spite of significant levels of financial support from the host institution, the considerable amount of time required to develop and maintain M-KEN was not built into the evaluation of the academic role.

7) Addressing the disparity in timescale between research delivery and stakeholder knowledge requirements.

We suggest that if KE activity is formally recognised as a core element in the typical academic role then researchers would have more opportunity to expediate tailored communication of knowledge to individual research users.

\section{Recommendations for future endeavours}

Our experiences with M-KEN demonstrate that there is short-term tangible benefit to 
environmental research and research user communities of setting up open KE networks; and likely significant longer-term impact benefits to society, through policy influence, innovation and new ways of working across sectors. Such a network draws on the underlying expertise and knowledge of researchers and the broad body of historical research which they have involvement and contact with, as well as the ongoing research for which research funders wish to see impact. Moreover, the impact of the network activity itself may be significant in changing working practices and funding sources and models within and between member institutions. Tracing the impact of such an initiative is challenging and resource-intensive so for a network to be selfjustifying it must reach some critical mass at which impact tracking and documenting can be adequately resourced as a key activity.

There are also significant costs associated with the development of such a network, particularly if it is run by academics who need to find significant overheads as well as salary to pay for staff time. Some costs are local to the events and meetings that are run and will scale linearly with the geographical size of the activity. However, significant efficiency and effectiveness could be gained by centralising administrative, management, communication and support activities and systems at e.g. national levels. We consider here how an internationally coordinated effort might make use of the funding and KE models pioneered by M-KEN, in the context of the drive to develop international initiatives such as OceanKAN (Bayliss-Brown et al, 2020) and more broadly Future Earth's Knowledge Action Networks across environmental and sustainability research.

What could be achieved by a small dedicated team coordinating and leading an international endeavour to develop a self-supporting, securely and well-funded 'Ocean Knowledge Exchange Network' ('Ocean-KEN') with national nodes around the world? We envisage a hybrid model for a hierarchy of 'nested' networks facilitating knowledge flow, decision making, best practice and innovation at a regional scale or smaller but linked as part of a 
larger network through national and international coordinating activities. As demonstrated by MKEN the value of the regional focus was to build a strong network of engaged actors who shared a drive to tackle a common set of challenges, with multiple lines of overlap between their work and that of others in the network and therefore significant personal, professional and institutional benefits to active participation. The proposed hierarchy of this approach is summarised in Figure 3.

A key question is that of funding for such an endeavour. M-KEN has demonstrated that self-interest has the capacity to drive the funding of the local-to-regional scale networks. For instance, a collaboration between a region's universities, local government, interested businesses and NGOs could co-fund a regional network with modest funding, if the resource intensive management of communications and funds and provision of stakeholder management systems were coordinated by national nodes. We see this as feasible - as demonstrated by M-KEN there are funds available in the research impact 'ecosystem' - from funders, from beneficiaries of research knowledge, and potentially by membership fees. We envisage national nodes could be run as fully commercial activities, not-for-loss / not-for-profit social enterprises or charities, depending on national conditions.

The Maritime Alliance Bluetech Cluster (https://www.tmabluetech.org/) based in San Diego California is an interesting example of a membership-supported network which started regionally but is growing an international network of research and commercial organisations under the shared vision of 'promoting sustainable science-based ocean and water industries'. Their aim is to develop national or regional 'BlueTech clusters' of marine industry. Engaging with and supporting such industry-led initiatives may be an important part of bringing what is currently a patchwork of ad hoc marine networks and clusters together under a common banner.

The origins of the Future Earth programme are strongly linked with the drive to increase the societal impact of global environmental and sustainability science (van der Hel, 2016) and is 
strongly aligned with the United Nations Sustainable Development Goals for 2030. Future Earth's Knowledge Action Networks aim to “identify and respond to society's needs for scientific knowledge to successfully undertake the transformation to sustainability" and "develop and cultivate research that is solution-driven, inter- and trans-disciplinary"

(https://futureearth.org/networks/knowledge-action-networks/). Future Earth's initiatives to deliver 'solutions-oriented', 'co-produced' research have been criticised by some social scientists on the basis of reducing academic freedom; 'monolithisation' of the challenges we face; potential bias; and misrepresentation of certain stakeholder groups (see Beck, 2019 for a full discussion). However, it is difficult to argue against a drive for interdisciplinary engagement and collaboration when the need to tackle the crises faced is urgent. In particular, effective coproduction and use of research knowledge and research capability with stakeholders to inform decision making and provide innovative solutions to societal/environmental problems is critical if society is to overcome the challenges of the anthropocene and progress towards a positive future (Bai et al., 2016).

Beck (2019) argues that one of the potential approaches to negate the aforementioned potentially negative socio-political effects of the top-down application of knowledge coproduction agendasis to initiate "nested, bottom-up, autonomous" approaches to dealing with the problems of the Anthropocene:

\footnotetext{
"Such distributed forms of engagement correspond with flexible, responsive, bottom-up approaches to politics and to a model of democracy as a set of complex networks of interlinked spaces in which deliberations occur (Miller 2009: 145). Each of these spaces exhibits norms and practices that correspond to multiple aspects of knowledge production: who participates, under what conditions, how participation is governed, how policy ideas are framed, evidentiary rules and standards, openness and transparency, and processes of review and certification. Such forms of alternative engagement may serve to facilitate coordination and cooperation even among people and organizations that are in many respects far apart. The Anthropocene as a narrative can serve to link these local initiatives to global agendas such as the Sustainable Development Goals. If insider and outsider forms of engagement are
} 
linked in a constructive or complementary way and are dovetailed with each other, distributed engagement with the Anthropocene can offer an independent form of evaluation in order to boost not only public accountability and the legitimacy of Future Earth's coproduction processes but also its responsiveness and its own institutional reflexivity."

The 'nationally-supported, internationally coordinated, regional KE network' model may therefore provide a solution to a multiplicity of challenges in making science work for societal good:

(1) All actors in the system are benefitting their own interests as well as the 'common good', but independent management at national level ensures no bias towards particular knowledge producers or commercial interests.

(2) Impacts and outcomes can be traced and documented, benefitting research institutions and research funders.

(3) Stakeholder fatigue and the 'multiplication of engagement' are avoided. Whilst we have focussed here (as M-KEN did) on policy and business impacts, we argue that other societal interactions such as education and community engagement could also be achieved through the same hierarchy of networks.

\section{Conclusion}

This paper has examined and assessed the activities of the Marine Knowledge Exchange Network in the contexts of both key questions arising in the KE literature and recommendations for future knowledge exchange networks. The experience of M-KEN leads us to make the following key observations and recommendations for effective knowledge exchange and impact from a portfolio of research:

\section{1) Build interdisciplinary networks to facilitate knowledge and impact discovery}


around a key topic / region / issue. Taking a 'portfolio' approach to the underpinning research knowledge but a bringing together a cross-sectoral, interdisciplinary network of stakeholders with strong shared interests is a powerful engine for knowledge discovery, brokerage, exchange and impact. New projects and truly interdisciplinary knowledge generation will follow

2) Independent, funded coordination of network coordination, knowledge mediation and impact tracing is ideal. While academic / university leadership can be seen by some stakeholders as appropriately independent, it has substantial shortcomings both in terms of institutional and individual self-interest, time and resource allocation constraints. The M-KEN experience demonstrates that there is ample funding available for impact activities so independent, appropriately funded (whether for-profit or otherwise) coordination hub(s) would allow for efficient use of resources to drive impact from research portfolios at national level, utilising selfsupporting or membership-based regional networks and interest groups.

3) Engage with the broadest range of stakeholders possible to facilitate disruptive change. Our novel approach of embedding graphic designers in the core M-KEN leadership team developed capacity in the production of marine science infographics and based on our experience we would firmly recommend the incorporation of non-typical actors in future KE networks (e.g. artists, designers, psychologists, film makers, bloggers etc) to generate new ideas, approaches and opportunities.

4) Support and incentivise the involvement of academic research by recognising $\mathrm{KE}$ network building and subsequent impact generation in academic career paths. As $\mathrm{KE}$ and impact activities become increasingly valued by research funders it is inevitable that such activities will increasingly be recognised for academics promoting their own research through promotions criteria in HE. However, a broader 'pathway' of specialising in $\mathrm{KE}$ and impact/innovation as $4^{\text {th }}$ core activity alongside teaching, research and administration could allow academics with particular motivation or aptitude to focus on such activities for the common benefit of their institution and peers.

M-KEN was envisaged as a novel approach to valorising research and building impact from it, taking the development of a regional social network as the essential starting point. This was successfully undertaken and this network and the approach that M-KEN took has gone on to influence marine KE activities nationally and internationally. We have demonstrated that the approach is particularly successful at achieving the early steps of research valorisation for a whole portfolio of research or community of researchers and as such, has the potential to operate across a global effort to make environmental science more effective at solving global challenges. However, the regional focus of M-KEN was one of its great strengths, with actors within the network sharing and identifying with common 'on the ground' issues and opportunities. For this 
reason, a nested 'hierarchy' of networks, with academic institutions as key contributors but not controllers, might be a powerful way to approach a global ocean KE network and mitigate some of the criticisms of the 'top-down' approaches to solving the grand challenges of our times.

\section{Acknowledgements}

We are grateful to the members and supporters of M-KEN for making waves! We gratefully acknowledge the financial support of the University of East Anglia, the Natural Environment Research Council (GRANT NUMBERS TBC-Blue Futures, NERC IAA), the Economic and Social Research Council (GRANT NUMBERS TBC - ESRC IAA) [others?].

\section{References}

Armstrong, F. and Alsop, A. (2010) Debate: co-production can contribute to research impact in the social sciences, Public Money \& Management, 30(4): 208-10.

Bai, X., van der Leeuw, S., O’Brien, K., Berkhout, F., Biermann, F., Brondizio, E. S., ... and Syvitski, J. (2016) Plausible and desirable futures in the Anthropocene: A new research agenda. Global Environmental Change, 39: 351-362. DOI: 10.1016/j.gloenvcha.2015.09.017

Bayliss-Brown, G.A, Gerhardinger, L.C. and Starger, C. (2020) Networked Knowledge to Action in Support of Ocean Sustainability. Coastal Management Journal, this issue

Beck, S. (2019). Coproducing Knowledge and Politics of the Anthropocene: The Case of the Future Earth Program. Anthropocene Encounters: New Directions in Green Political Thinking, 191-211. DOI:10.1017/9781108646673.010

Bednarek, A.T, Wyborn, C, Cvitanovic, C, Meyer, R, Colvin, R.M, Addison, P.F.E, ... and Leith, P. (2018) Boundary spanning at the science-policy interface: the practitioners perspectives. Sustainability Science, 13: 1175-1183. DOI: /10.1007/s11625-018-0550-9

Bracken, L.J., Bulkeley, H.A. and Whitman, G. (2015) Transdisciplinary research: understanding the stakeholder perspective. Journal of Environmental Planning and Management, 58 (7), 1291-1308, DOI: 10.1080/09640568.2014.921596 
Chubb, J., and Watermeyer, R. (2017) Artifice or integrity in the marketization of research impact? Investigating the moral economy of (pathways to) impact statements within research funding proposals in the UK and Australia. Studies in Higher Education, 42(12), 2360-2372. DOI: 10.1080/03075079.2016.1144182

COLUMBUS (2018a) COLUMBUS Blue Society Knowledge Transfer Handbook [pdf] Available at: http://www.columbusproject.eu/D8.5\%20Handbook_v2_Final.pdf Accessed on: 27 May 2020

COLUMBUS (2018b) Recommendations for European and national funding agencies to embed Knowledge Transfer in current and future funding [pdf]Available at: http://www.columbusproject.eu/D8.6\%20COLUMBUS\%20Recommendations\%20for\%2 0Funding\%20Agencies_May2018.pdf Accessed on: 27 May 2020

COLUMBUS (2018c) COLUMBUS stories of marine and maritime Knowledge Transfer activities [pdf] Available at:

http://www.columbusproject.eu/CCV7_FINAL_0.1_compressed.pdf Accessed on: 27 May 2020

Cook, C.N., Mascia, M.B., Schwartz, M.W., Possingham, H.P. and Fuller, F.A.

(2013a)Achieving conservation science that bridges the knowledge action boundary. Conservation Biology, 27: 669-678

Cvitanovic, C., Hobday, A.J., van Kerkhoff, L., Wilson, S.K., Dobbs, K. and Marshall, N.A. (2015) Improving knowledge exchange among scientists and decision makers to facilitate the adaptive governance of marine resources: A review of knowledge and research needs. Ocean and Coastal Management, 112: 25-35

Cvitanovic, C., Cunningham, R., Dowd, A.-M., Howden, S.M. and van Putten, E.I. (2017) Using Social Network Analysis to Monitor and Assess the Effectiveness of Knowledge Brokers at Connecting Scientists and Decision-Makers: An Australian Case Study. Environmental Policy and Governance, 27(3): 256-269. DOI: 10.1002/eet.1752 
DANDELION (2018) Innovative, inclusive and reflective societies-sensitive Valorisation Concept [pdf] Available at: http://www.dandelioneurope.eu/imagem/IIRS_sensitive_Valorisation_Concept.pdf Accessed on: 27 May 2020

Day, S.A., Tolhurst, T.J., Lorenzoni, I., Johnson, M.T., Kennedy, K., Dunnett, I., Forster, J., ... and Southern, A. (2018) Blue Opportunities from the future: Knowledge and tools to inform sustainable growth for an integrated terrestrial, coastal and marine zone economy - a summary report. Marine Knowledge Exchange Network (MKEN), School of Environmental Sciences, University of East Anglia, Norwich. DOI: 10.6084/m9.figshare.7649492

Dorémus, L. (2017). Stakeholder Engagement, Moving from Quantity to Quality. Minutes of EU-Polarnet session at ICASS IZX, Umeå, Swede, 08 June 2017. EU-PolarNet. Retrieved from https://www.eu-polarnet.eu/fileadmin/user_upload/www.eupolarnet.eu/Members_documents/Deliverables/WP4/D4_9_Minutes_of_stakeholder_dialog $\underline{\text { ue at_Arctic_Conference.pdf }}$

European Commission (2020) PESETA IV [html] Available at: https://ec.europa.eu/jrc/en/pesetaiv Accessed on: 27 May 2020.

Fabian, Y., Bollmann, K., Brang, P., Heiri, C., Olschewski, R., Rigling, A., Stofer, S. and Holderegger, R. (2019) How to close the science-practice gap in nature conservation? Information sources used by practitioners. Biological Conservation, 235: 93-101

Fazey, I., Bunse, L., Msika, J., Pinke, M., Preedy, K., Evely, A.C., ... . and Reed, M.S. (2014) Evaluating knowledge exchange in interdisciplinary and multi-stakeholder research. Global Environmental Change, 25: $204-220$

Fazey, I., Evely, A.C., Reed, M.S., Stringer, L.C., Kruijsen, J., White, P.C., ... and Blackstock, K. (2013) Knowledge exchange: a review and research agenda for environmental management. Environmental Conservation, 40(1):19-36.

Greenhalgh, T., Jackson, C., Shaw, S. and Janamian, T. (2016) Sensitizing Concepts In: The SAGE Encyclopedia of Qualitative Research Methods. The Milbank Quarterly, 94(2): 392429.

Hill, S. (2016) Assessing (For) Impact: Future Assessment of the Societal Impact of Research.Palgrave Communications, 2 (May): 1-7. DOI: 10.1057/palcomms.2016.73. Huggins, R., Johnston, A. and Steffenson, R. (2008) Universities, Knowledge Networks and Regional Policy.Cambridge Journal of Regions, Economy and Society, 1(2): 321-40. DOI: $10.1093 /$ cjres/rsn013. 
Johnson, M.T., Kennedy, K, Watkinson, A., Heywood, K, Jickells, T, Malin, G, Liss, P.S. and Richardson, D. (2015) The North Sea Under Pressure: is regional marine co-operation the answer? - Response from the University of East Anglia and NERC-funded Marine Knowledge Exchange Network. Submitted to Baroness Scott of Needham Market, leader of the House of Lords EU sub-committee on Energy and Environment.

Kröger, S., Parker, R., Cripps, G. and Williamson, P. (2018) Shelf Seas: The Engine of Productivity, Policy Report on NERC-Defra Shelf Sea Biogeochemistry programme. Cefas, Lowestoft. DOI: 10.14465/2018.ssb18.pbd

Legge O, Johnson M, Hicks N, Jickells T, Diesing M, Aldridge J, Andrews J, Artioli Y, Bakker DCE, Burrows MT, Carr N, Cripps G, Felgate SL, Fernand L, Greenwood N, Hartman S, Kröger S, Lessin G, Mahaffey C, Mayor DJ, Parker R, Queirós AM, Shutler JD, Silva T, Stahl H, Tinker J, Underwood GJC, Van Der Molen J, Wakelin S, Weston K and Williamson P (2020) Carbon on the Northwest European Shelf: Contemporary Budget and Future Influences. Front. Mar. Sci. 7:143. doi: 10.3389/fmars.2020.00143

Manville, C., Morgan Jones, M., Henham, M-L., Castle-Clarke, S., Frearson, M., Gunashekar, S. and Grant, J. (2015). Preparing impact submissions for REF 2014: An Evaluation, RAND Europe, Cambridge, UK [pdf] Available at: https://www.rand.org/content/dam/rand/pubs/research_reports/RR700/RR726/RAND_RR7 26.pdf. Accessed on: 23 May 2020

McInerny, G. J., Chen, M., Freeman, R., Gavaghan, D., Meyer, M., Rowland, F., ... Hortal, J. (2014). Information visualisation for science and policy: Engaging users and avoiding bias. Trends in Ecology and Evolution, 29(3), 148-157. DOI: 10.1016/j.tree.2014.01.003

Morgan Jones, M., Manville, C. and Chataway, J. (2017) Learning from the UK's Research Impact Assessment Exercise: A Case Study of a Retrospective Impact Assessment Exercise and Questions for the Future. Journal of Technology Transfer, 1-25. DOI: 10.1007/s10961-017-9608-6.

NERC (2018) NERC Research Grants and Fellowships Handbook, v2.0. Swindon, UK.

Nguyen, V.M., Young, N. and Cooke, S.J. (2016). A roadmap for knowledge exchange and mobilization research in conservation and natural resource management. Conservation Biology, 31(4): 789-798. DOI: 10.1111/cobi.1285

Osmond, D.L., Nadkarni, N.M., Driscoll, C.T., Andrews, .E, Gold, A.J., Broussard Allred, S.R., ... and Groffman, P.M. (2010) Front Ecol Environ 8(6): 306-313 
Ostle, C., Williamson, P., Artioli, Y., Bakker, D.C.E., Birchenough, S., Davis, C.E., ... and Watson, A.J. (2016) Carbon dioxide and ocean acidification observations in UK waters: Synthesis report with a focus on 2010-2015. University of East Anglia, UK.

Ozanne J.L., Davis, B., Murray, J.B., Grier, S., Benmecheddal, A., Downey, H., ... and Veer, E. (2017) Assessing the Societal Impact of Research: The Relational Engagement Approach. Journal of Public Policy \& Marketing, 36(1). DOI: 10.1509/jppm.14.121

Pearce, S. and Evans, D. (2018) The Rise of Impact in Academia: Repackaging a Long-Standing Idea British Politics, 13(3): 348-60. DOI: 10.1057/s41293-018-0079-7.

Penfield, T., Baker, M.J., Scoble, R. and Wykes, M.C. (2014) Assessment, Evaluations, and Definitions of Research Impact: A Review. Research Evaluation, 23(1): 21-32. DOI:10.1093/reseval/rvt021.

Perez Vico, E., Hellsmark, H. and Jacob, M. (2015) Enacting knowledge exchange: a context dependent and 'role-based' typology for capturing utility from university research, I, 33(1), 3-20. DOI: 10.1080/08109028.2015.1060699

Porter, M.K., Ní Cheallacháin, C., Bayliss-Brown, G.A. and Murphy, D. (2019a) Knowledge Transfer Guidelines and Recommendations for Irish Funding Agencies: How to Embed Knowledge Transfer Principles into Irish Funding Programmes to Help Maximise Measurable Impacts from Public Investments. EPA: Ireland.

Porter, M.K., Ní Cheallacháin, C., Bayliss-Brown, G.A. and Murphy, D. (2019b) Research to Policy Impact through Effective Knowledge Transfer [html] EPA: Ireland.

Reed, M.S., Stringer, L.C., Fazey, I., Evely, A.C., and Kruijsen, J.H.J. (2014) Five principles for the practice of knowledge exchange in environmental management Journal of Environmental Management, 146: 337-345.

Smith, K.E. and Stewart, E. (2017) We Need to Talk about Impact: Why Social Policy Academics Need to Engage with the UK's Research Impact Agenda. Journal of Social Policy, 46 (1): 109-127. DOI: 10.1017/S0047279416000283.

Spender, J. C., Corvello, V., Grimaldi, M., and Rippa, P. (2017) Startups and open innovation: a review of the literature. European Journal of Innovation Management, 20(1), 4-30. https://doi.org/10.1108/EJIM-12-2015-0131

UKRI (2020) Knowledge Exchange Framework [html] Available at: https://re.ukri.org/knowledge-exchange/knowledge-exchange-framework/ Accessed on: 27 May 2020 
van der Hel, S. (2016). New science for global sustainability? The institutionalisation of knowledge co-production in Future Earth. Environmental Science and Policy, 61, 165-175. https://doi.org/10.1016/j.envsci.2016.03.012

van Drooge, L., van, Vandeberg, R., Zuijdam, F., Mostert, B., van der Meulen, B. and van der, \& Bruins, E. (2015). Valuable - Indicators for valorisation. [pdf] Available at: The Hague. Retrieved from

http://www.rathenau.nl/uploads/tx_tferathenau/ReportValuable.pdfhttps://pure.knaw.nl/ws/ portalfiles/portal/474286/Valuable.pdf Accessed on: 27 May 2020

Visbeck, M. (2018) Ocean science research is key for a sustainable future. Nature Communications, 9(1), 1-4. DOI: 10.1038/s41467-018-03158-3 
Table 1. Impact readiness levels for social sciences and health research (SSH) by DANDELION 2018, adapted here for broader application by removal of references to SSH. Descriptor for each

IRL (Discovery, Engagement, Implementation, Uptake, Impact) defined and added by the current study.

\begin{tabular}{|c|c|c|c|c|}
\hline IRL1 & IRL 2 & IRL 3 & IRL 4 & IRL 5 \\
\hline Discovery & Engagement & Implementation & Uptake & Impact \\
\hline $\begin{array}{l}\text { KEY TRAITS: } \\
\text { - Mapping \& analysis of the } \\
\text { stakeholders landscape in } \\
\text { order to grasp the value chain } \\
\text { of the envisioned research } \\
\text { outputs } \\
\text { - Definition of instruments } \\
\text { and strategic planning of } \\
\text { outreach activities in order to } \\
\text { create value } \\
\text { - Successful communication } \\
\text { of research to key target } \\
\text { audiences at a medium/late } \\
\text { stage of the project } \\
\text { - Research agenda and } \\
\text { process are co-designed with } \\
\text { the potential stakeholders }\end{array}$ & $\begin{array}{l}\text { KEY TRAITS: } \\
\text { - Organisation of / } \\
\text { participation in multi- } \\
\text { stakeholder events with a } \\
\text { common agenda } \\
\text { - Successful outreach and } \\
\text { systematic, planned } \\
\text { involvement of various media } \\
\text { channels } \\
\text { - Scientific knowledge } \\
\text { circulates along various } \\
\text { channels in a stakeholder- } \\
\text { sensitive language } \\
\text { - Early systematic exploration } \\
\text { with specific stakeholders } \\
\text { about requirements, barriers, } \\
\text { opportunities for potential } \\
\text { application }\end{array}$ & $\begin{array}{l}\text { KEY TRAITS: } \\
\text { - The basis for research } \\
\text { application is established } \\
\text { through an iterative co- } \\
\text { creation process } \\
\text { - Consolidation and } \\
\text { validation of 'actionable' } \\
\text { results of research by } \\
\text { stakeholders in practice } \\
\text { - First implementation efforts } \\
\text { can be demonstrated as single } \\
\text { one-off events in a concrete } \\
\text { societal context of } \\
\text { application } \\
\text { - Societal stake- holders are } \\
\text { engaged in research } \\
\text { evaluation and support } \\
\text { learning feedback loops for } \\
\text { researchers }\end{array}$ & $\begin{array}{l}\text { KEY TRAITS: } \\
\text { - Demonstrable uptake of } \\
\text { research results and their } \\
\text { advancement through } \\
\text { entering a for-profit/ not-for- } \\
\text { profit enduring partnership } \\
\text { with stakeholders } \\
\text { - Sustainability of the multi- } \\
\text { stakeholder process is } \\
\text { planned for in previous stages } \\
\text { and appears highly probably } \\
\text { - Beneficial outcomes on } \\
\text { target stakeholder groups are } \\
\text { verifiable } \\
\text { - Research triggers a change } \\
\text { in funding institutions and } \\
\text { their schemes, and also in the } \\
\text { visibility and the positioning } \\
\text { of the societal dimensions of } \\
\text { 'Third Mission' in PROs and } \\
\text { RTOs }\end{array}$ & $\begin{array}{l}\text { KEY TRAITS: } \\
\text { - Demonstrable scale-up and } \\
\text { follow-ups both in regional and } \\
\text { sectoral terms; emergence of } \\
\text { SSH spinoffs } \\
\text { - The initiators/researchers are } \\
\text { recognised as innovators and } \\
\text { are consulted for advice for } \\
\text { replication of good practices } \\
\text { - The application of research in } \\
\text { different contexts generates } \\
\text { additional demand with funding } \\
\text { organisations for further } \\
\text { innovative research } \\
\text { - Beneficial outcomes are } \\
\text { measurable and introduce not } \\
\text { merely a change in practice but } \\
\text { moreover a sustainable change } \\
\text { in mindsets, culture, regulation }\end{array}$ \\
\hline
\end{tabular}


Table 2. An analysis of the IRL achieved by a selection of M-KEN activities. In the absence of M-KEN these opportunities for research valorisation would not have arisen so we consider the IRL to change from zero to the value assigned in the final column of the table for the underlying research, with specific reference to these activities.

\begin{tabular}{|l|l|l|l|}
\hline Activity/ies & $\begin{array}{l}\text { Underlying } \\
\text { research }\end{array}$ & Outputs (O), influences (I), Outcomes (OC) & IRL \\
\hline $\begin{array}{l}\text { M-KEN-led Response } \\
\text { to report “The North } \\
\text { Sea Under Pressure..." } \\
\text { (House of Lords, 2014) }\end{array}$ & $\begin{array}{l}\text { Portfolio, } \\
\text { NERC SSB } \\
\text { Blue Carbon } \\
\text { project }\end{array}$ & $\begin{array}{l}\text { I: M-KEN organised meeting with marine scientists and chair of House of Lords committee } \\
\text { O: M-KEN led response to report highlighting relevant research and key issues (Johnson et al., 2015) } \\
\text { OC: M-KEN response considered and disseminated by committee, further outcomes not tangible }\end{array}$ \\
\hline $\begin{array}{l}\text { M-KEN open events } \\
\text { (InfoHackit, } \\
\text { EnvEXPO, } \\
\text { networking) }\end{array}$ & Portfolio & $\begin{array}{l}\text { I: Large numbers of stakeholders engaged in M-KEN's “mission" } \\
\text { OC: Stronger network and better mutual understanding of opportunities for co-production. Capacity building in } \\
\text { creative industries in Norwich for research communication }\end{array}$ & 2-3 \\
\hline $\begin{array}{l}\text { NERC Environmental } \\
\text { Science Impact Fund } \\
\text { and Regional Impact of } \\
\text { Science of the } \\
\text { Environment bids: } \\
\text { 'Blue-Green Economy } \\
\text { East' and 'Anglian } \\
\text { RISE' }\end{array}$ & Portfolio & $\begin{array}{l}\text { O: £2M bid to NERC's flagship regional impact and innovation fund in 2016, led by M-KEN team and drawing } \\
\text { strongly on M-KEN's stakeholder community to co-design a transformative regional plan for making East } \\
\text { Anglia the flagship 'blue-green economy' in the UK. Subsequent contribution to a second bid (ARISE) led by } \\
\text { University of Cambridge. } \\
\text { I: Further strengthening the regional network, propagating latest thinking around environmental economics to } \\
\text { stakeholder-partners } \\
\text { OC: Although not funded (very close to success) numerous components of the proposal have developed } \\
\text { separately after the relationships and ideas were developed, such as the East Anglian Natural Capital Valuation } \\
\text { project (Lovett et al., 2019). }\end{array}$ & 4 \\
\hline $\begin{array}{l}\text { Blue Futures (ongoing) } \\
\text { O: Project brochure, academic paper, briefings to policy makers (e.g. Government Office for Science) }\end{array}$ & \\
\hline
\end{tabular}




\begin{tabular}{|c|c|c|c|}
\hline & & $\begin{array}{l}\text { I: Integration of 'blue' economy agenda into the development of a regional } 25 \text { year Environment Plan. } \\
\text { OC: Stronger relationships between MKEN and general sustainability agenda in Eastern Region; ideas seeded } \\
\text { for future collaborative projects; project team capacity and skill set well promoted - e.g. workshop facilitation. }\end{array}$ & \\
\hline $\begin{array}{l}\text { Policy report cards } \\
\text { produced or supported } \\
\text { by M-KEN }\end{array}$ & $\begin{array}{l}\text { NERC SSB } \\
\text { Programme } \\
\text { NERC Blue } \\
\text { Futures } \\
\text { NERC OA } \\
\text { Programme }\end{array}$ & $\begin{array}{l}\text { O: Report cards: Kroeger et al., 2018; Day et al., 2019; Ostle et al., } 2017 \\
\text { I: Reports reach evidence managers in Defra and in case of Ostle et al., 2017, reach and influence minister. } \\
\text { OC: ongoing discussions by project scientists with Defra. Tangible impact beyond this not currently traceable. }\end{array}$ & $\begin{array}{l}3 \\
\text { (potential } \\
\text { ly } 5 \text { if } \\
\text { policy } \\
\text { change } \\
\text { occurs) }\end{array}$ \\
\hline $\begin{array}{l}\text { Norfolk and Suffolk } \\
\text { Coastal Network } \\
\text { (NSCN) and Coastal } \\
\text { Partnership East (CPE) }\end{array}$ & Portfolio & $\begin{array}{l}\text { O: New network and partnerships developing around knowledge-led coastal management in the East Anglian } \\
\text { region. } \\
\text { I: M-KEN supported the formation and development of the Norfolk and Suffolk Coastal Network, which led on } \\
\text { to CPE and also led regional 'knowledge audit' co-funded by local council } \\
\text { OC: Bacton to Whalcott Sandscaping project (massive addition of sand to travel down coast and inhibit coastal } \\
\text { erosion) evolves from CPE. Coastal natural and social scientists more involved in regional coastal decisions. }\end{array}$ & $3-4$ \\
\hline NEF Blue new deal & Blue Futures & $\begin{array}{l}\text { I: New Economics Foundation interested in Blue Futures and incorporated some of the qualitative findings and } \\
\text { thinking into their Blue New Deal 'manifesto' launched to MPs at Westminster in } 2016 \text { (M-KEN represented at } \\
\text { launch). } \\
\text { OC: Indirect influence on thinking around Coastal management. Very difficult to trace M-KEN's impact }\end{array}$ & $3-4$ \\
\hline
\end{tabular}


Table 3. Benefits and risks to stakeholders engaged in a university-led knowledge network

\begin{tabular}{|c|c|c|c|}
\hline Stakeholder & Inputs to network & Benefits from network & Risks of involvement \\
\hline $\begin{array}{l}\text { Academic individuals } \\
\text { running the network }\end{array}$ & Time, knowledge, expertise & $\begin{array}{l}\text { Kudos, enhanced professional network, career } \\
\text { development }\end{array}$ & $\begin{array}{l}\text { Very large opportunity cost if not core to job role, } \\
\text { reputational risk. }\end{array}$ \\
\hline $\begin{array}{l}\text { Paid consultants } \\
\text { involved in running the } \\
\text { network }\end{array}$ & $\begin{array}{l}\text { Time, knowledge, expertise, } \\
\text { IP, contacts }\end{array}$ & $\begin{array}{l}\text { Income, enhanced professional network, new } \\
\text { opportunities }\end{array}$ & $\begin{array}{l}\text { Reputational risk if activities unsuccessful, somewhat } \\
\text { at the mercy of academics' ability to deliver }\end{array}$ \\
\hline Individual members & Time, knowledge, expertise & $\begin{array}{l}\text { Enhanced professional network, new opportunities, } \\
\text { career development }\end{array}$ & Small opportunity cost. \\
\hline $\begin{array}{l}\text { Academic institution(s) } \\
\text { supporting / hosting } \\
\text { network }\end{array}$ & $\begin{array}{l}\text { Resource (staff time, funds, } \\
\text { estates costs etc). }\end{array}$ & $\begin{array}{l}\text { Raised profile, impact, increased research funding } \\
\text { success, new opportunities for income and } \\
\text { commercialisation }\end{array}$ & Opportunity cost, reputational damage. \\
\hline $\begin{array}{l}\text { Commercial } \\
\text { organisations }\end{array}$ & $\begin{array}{l}\text { Staff time, possibly } \mathrm{R}+\mathrm{D} \\
\text { investment }\end{array}$ & $\begin{array}{l}\text { New income opportunities, better corporate social } \\
\text { responsibility outcomes, new partnerships }\end{array}$ & $\begin{array}{l}\text { Opportunity cost ( directly affecting bottom line in } \\
\text { commercial case) }\end{array}$ \\
\hline $\begin{array}{l}\text { Policy / government } \\
\text { organisations }\end{array}$ & $\begin{array}{l}\text { Expertise, evidence needs, } \\
\text { policy insight/ foresight }\end{array}$ & Better evidence for decision making & $\begin{array}{l}\text { Possible bias to certain groups / interests / scientific } \\
\text { opinions if knowledge network is not broad / impartial } \\
\text { enough }\end{array}$ \\
\hline Practitioners & Knowledge, expertise, time & $\begin{array}{l}\text { Faster translation of research into improvements in } \\
\text { practice, new funding opportunities for projects, new } \\
\text { partnerships,access to collective knowledge in the } \\
\text { network (not solely academic). }\end{array}$ & $\begin{array}{l}\text { Sharing otherwise unique 'on the ground' knowledge to } \\
\text { wider group (potentially seen by some as a negative), } \\
\text { opportunity cost. }\end{array}$ \\
\hline
\end{tabular}




\begin{tabular}{|l|l|l|l|}
\hline Charities / other NGOs & Knowledge, expertise, time & $\begin{array}{l}\text { Better decision making and practice for particular } \\
\text { interest area }\end{array}$ & $\begin{array}{l}\text { Opportunity cost considerable due to very limited } \\
\text { resources }\end{array}$ \\
\hline Wider society & $\begin{array}{l}\text { Highlighting locally, } \\
\text { regionally and globally } \\
\text { important social and } \\
\text { environmental issues }\end{array}$ & $\begin{array}{l}\text { Better decision making, improved environmental } \\
\text { status, new employment opportunities, more } \\
\text { responsible private sector activities. }\end{array}$ & - \\
\hline
\end{tabular}


Table 4. Insights into key questions and concepts in the KE research literature arising from the experiences of M-KEN. Here, key research questions and concepts are grouped by subjective assessment of their commonalities and a commentary is provided based on the experiences of MKEN documented in this paper and the associated supplemental material.

\begin{tabular}{|c|c|c|c|}
\hline \multicolumn{2}{|c|}{ Observations, questions and concepts arising in literature } & References & Insights arising from M-KEN experience \\
\hline $\begin{array}{l}\text { 1. Integration of } \\
\text { knowledge exchange } \\
\text { in the design, } \\
\text { development and } \\
\text { delivery of research } \\
\text { projects. }\end{array}$ & $\begin{array}{l}\text { Potential to increase the impact of environmental research by } \\
\text { embedding knowledge exchange in research, and co- } \\
\text { generation of new knowledge through long-term dialogue and } \\
\text { networking between researchers and stakeholders. } \\
\text { All stakeholders are also knowledge holders, translators and } \\
\text { producers and to some extent knowledge exchange and truly } \\
\text { interdisciplinary research are one-and-the-same. New insights } \\
\text { and innovations arise from the cross-fertilisation of multi- } \\
\text { stakeholder knowledge exchange. }\end{array}$ & $\begin{array}{l}\text { Reed et al. 2014, } \\
\text { Cvitanovic et al. } \\
\text { 2015, Fazey et al. } \\
\text { 2014, Hill, } 2016 \\
\text { e.g. Bracken et al., } \\
\text { 2014, Fazey et al., } \\
\text { 2014, Visbeck } 2019 \text {, } \\
\text { Fazey et al., } 2013\end{array}$ & $\begin{array}{l}\text { Our experience very much supports the idea that impact can be facilitated } \\
\text { by a long-term, multi-stakeholder approach. Probably the most significant } \\
\text { legacy of M-KENs efforts over the time period considered in this paper is } \\
\text { the network of new relationships between individual members of the } \\
\text { network, many of which now involve academic researchers in extensive } \\
\text { dialogue and collaborations with research users. } \\
\text { The network-based approach led to new opportunities for academic and } \\
\text { non-academic members alike, and the learning process of bidirectional } \\
\text { 'knowledge discovery' was a key part of building relationships and cross- } \\
\text { fertilisation. The independent (or semi-independent) network } \\
\text { structure developed by M-KEN facilitated this. }\end{array}$ \\
\hline
\end{tabular}




\begin{tabular}{|c|c|c|c|}
\hline & $\begin{array}{l}\text { What are the different kinds of institutional structures that are } \\
\text { relevant to and affect opportunities for co-generation of } \\
\text { knowledge? }\end{array}$ & & \\
\hline $\begin{array}{l}\text { 2. Development and } \\
\text { utilisation of a } \\
\text { framework for } \\
\text { knowledge exchange } \\
\text { activity. }\end{array}$ & $\begin{array}{l}\text { Conceptual frameworks needed to provide a road map for } \\
\text { future research and KE activities to understand and remedy } \\
\text { the knowledge action gap. More research is needed to understand } \\
\text { the influence of context and external forces on knowledge } \\
\text { mobilization outcomes. } \\
\text { Framework proposed by Nguyen et al., } 2016 \text { includes a } \\
\text { mediation sphere which influences and mediates the flow of } \\
\text { knowledge from production to action - this could be a } \\
\text { knowledge network or a social network composed of multiple } \\
\text { actors ranging from groups to institutions with a collective and } \\
\text { individual responsibility in the mobilisation of knowledge }\end{array}$ & $\begin{array}{l}\text { Nguyen et al., 2016, } \\
\text { Fazey et al., } 2014\end{array}$ & $\begin{array}{l}\text { In the process of building relationships and facilitating KE activities, M- } \\
\text { KEN became a mediating organisation between knowledge and its end } \\
\text { users. That the academic leads of M-KEN were working for the network } \\
\text { and often not for research that they directly represented, along with the the } \\
\text { independent consultancy support from Blue Ltd facilitated the } \\
\text { 'independence' of M-KEN. Whilst the academics whose research was } \\
\text { being presented could in some cases be mediators, often the self- } \\
\text { interest of one's own research interfered. Further on in the process } \\
\text { when M-KEN-derived research activity such as Blue Futures was ongoing, } \\
\text { the mediation relationship was different but still existed, in that the } \\
\text { research knowledge represented was a broad portfolio being synthesised } \\
\text { by the project team. }\end{array}$ \\
\hline $\begin{array}{l}\text { 3. Utilising } \\
\text { dedicated } \\
\text { knowledge brokers }\end{array}$ & $\begin{array}{l}\text { Use of knowledge brokers/boundary organisations/boundary } \\
\text { spanning to improve collaboration and KE across the } \\
\text { knowledge action boundary and support evidence-based }\end{array}$ & $\begin{array}{l}\text { Cvitanovic et al. } \\
\text { 2015, Cvitanovic et }\end{array}$ & $\begin{array}{l}\text { M-KEN was ultimately a knowledge brokerage organisation. In } \\
\text { respect of the } 2 \text { points above, all members of the network were } \\
\text { arguably knowledge brokers and shared a responsibility for the }\end{array}$ \\
\hline
\end{tabular}




\begin{tabular}{|c|c|c|c|}
\hline $\begin{array}{l}\text { to facilitate multi- } \\
\text { stakeholder } \\
\text { knowledge } \\
\text { exchange. }\end{array}$ & $\begin{array}{l}\text { decision making. Viewed as a distinct and emerging practice } \\
\text { with dedicated facilitators of knowledge exchange between } \\
\text { and among various stakeholders and groups. To use } \\
\text { knowledge effectively and to address complex environmental } \\
\text { problems of relevance to multiple stakeholders, interaction is } \\
\text { required between knowledge producers and users. }\end{array}$ & $\begin{array}{l}\text { al. 2017, Cook et al. } \\
\text { 2013a, } \\
\text { Nguyen et al. } 2016 \text {, } \\
\text { Bednarek et al. } 2018\end{array}$ & $\begin{array}{l}\text { collective knowledge accumulated. Had ongoing funding been } \\
\text { secured the next stage of M-KEN would have built interdisciplinary } \\
\text { consortia of academics, practitioners, businesses and policy makers } \\
\text { to affect change directly through applied interdisciplinary research. } \\
\text { So whilst interaction is needed between knowledge producers and } \\
\text { users, the real benefit probably happens when these distinctions are } \\
\text { blurred by interdisciplinary collaboration. }\end{array}$ \\
\hline $\begin{array}{l}\text { 4. Synthesis of } \\
\text { research outcomes } \\
\text { to provide focused } \\
\text { and effective } \\
\text { knowledge exchange } \\
\text { outputs. }\end{array}$ & $\begin{array}{l}\text { Boundary or interface organisations are most effective when } \\
\text { focussed on specific issues in a specific location, and are } \\
\text { improved in effectiveness when synthesising, translating and } \\
\text { taking scientific results directly to decision makers through } \\
\text { targeted documents, presentations and small meetings. } \\
\text { Professionals are primarily time limited in their ability to } \\
\text { engage with the academic community, with little time to read } \\
\text { lengthy reports or international scientific journals }\end{array}$ & Osmond et al. 2010, & $\begin{array}{l}\text { The common interest in regional issues certainly helped to cement } \\
\text { the network and develop the beginning of a collective responsibility } \\
\text { for regional knowledge (underpinned by a feeling of collective } \\
\text { responsibility for the region's environment, society and economy). } \\
\text { The use of visual communication as well as small 'round table' } \\
\text { meetings was a powerful way of engaging and communicating } \\
\text { knowledge to research users. } \\
\text { Knowledge brokering involves translating and presenting research } \\
\text { findings in a context and format applicable to the end-user. } \\
\text { Infographics are flexible, applicable to a wide audience, quick to }\end{array}$ \\
\hline
\end{tabular}




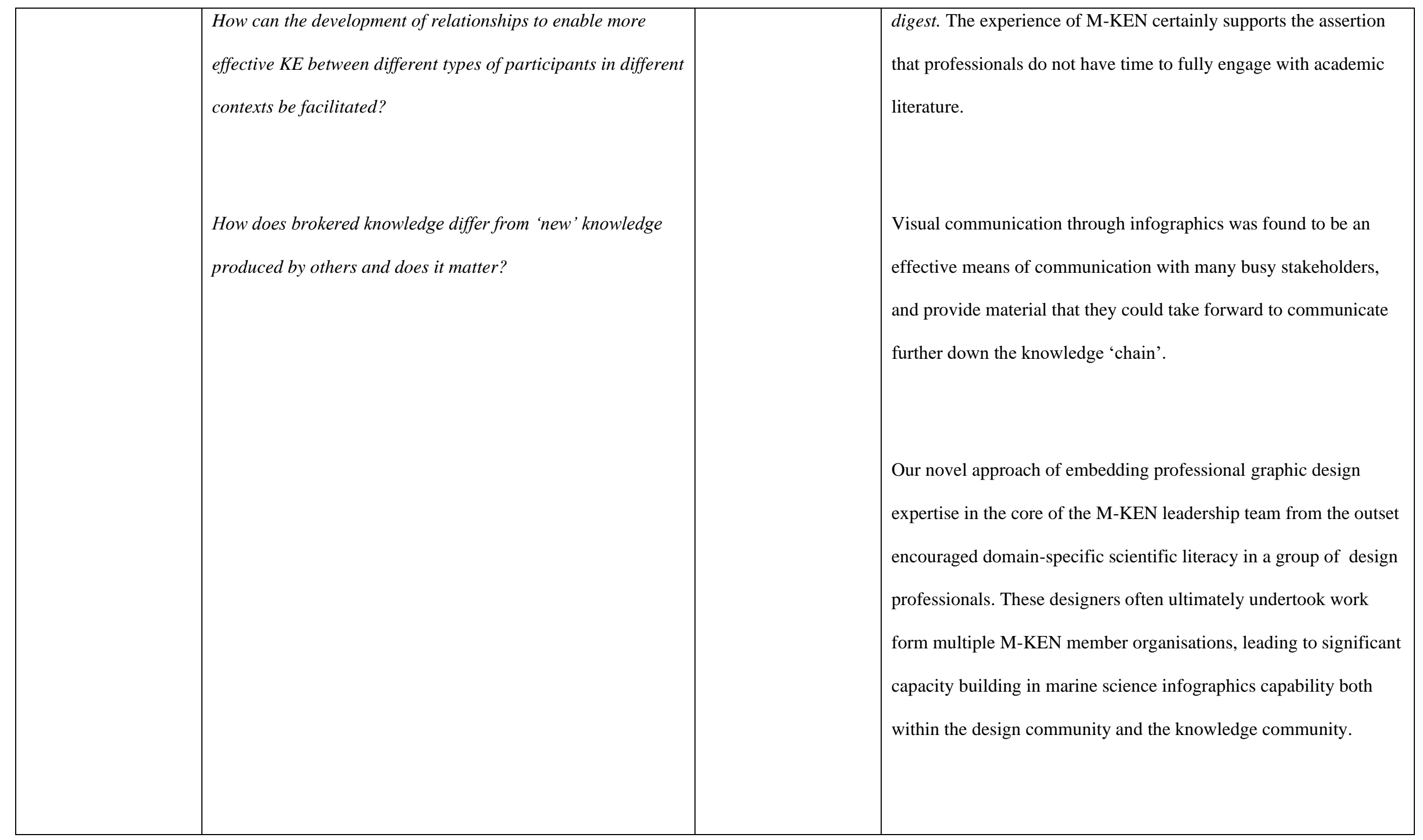




\begin{tabular}{|c|c|c|c|}
\hline & & & $\begin{array}{l}\text { We recommend that KENs should embrace a holistic } \\
\text { interdisciplinarity and incorporate non-typical actors from the } \\
\text { beginning (e.g. artists, designers, psychologists) to break the } \\
\text { traditional boundaries and silos in research / knowledge exchange } \\
\text { and cultivate disruptive change. }\end{array}$ \\
\hline $\begin{array}{l}\text { 5. Long-term } \\
\text { assessment and } \\
\text { monitoring of } \\
\text { knowledge exchange } \\
\text { activities. }\end{array}$ & $\begin{array}{l}\text { Increase impact potential by monitoring and reflecting, } \\
\text { learning and refining practice and considering how to sustain a } \\
\text { legacy of knowledge exchange beyond project funding. }\end{array}$ & $\begin{array}{l}\text { Reed et al. 2014, } \\
\text { Fazey et al. } 2013\end{array}$ & $\begin{array}{l}\text { The model of a domain-specific knowledge exchange network } \\
\text { representing a portfolio of research and knowledge facilitates } \\
\text { knowledge exchange well beyond the funding of a particular } \\
\text { project. As well as exchanging particular 'pieces' of knowledge, M- } \\
\text { KEN was able to build and secure funding for new research and } \\
\text { innovation activities in collaboration with practitioners, businesses } \\
\text { and policymakers, using the collective portfolio of knowledge and } \\
\text { expertise, with research knowledge applied to tackle key questions/ } \\
\text { problems / opportunities. } \\
\text { Also see point above regarding capacity building in visual } \\
\text { communication. }\end{array}$ \\
\hline
\end{tabular}




\begin{tabular}{|c|c|c|c|}
\hline $\begin{array}{l}\text { 6. Incentivising and } \\
\text { valuing knowledge } \\
\text { exchange activities, } \\
\text { particularly within } \\
\text { a research context. }\end{array}$ & $\begin{array}{l}\text { Institutional barriers/dis-incentives that undermine KE e.g. } \\
\text { inadequate measures of science impact/success for KE or } \\
\text { boundary spanning activities. KE / impact Activity is not } \\
\text { recognised in typical academic evaluation procedures, } \\
\text { institutional structures. } \\
\text { What in incentives and professional support are needed to } \\
\text { enhance the development of knowledge brokering skills? } \\
\text { How do incentive structures need to be different, or what } \\
\text { kinds of incentives need to be introduced to enable } \\
\text { researchers to engage more in effective KE?) }\end{array}$ & $\begin{array}{l}\text { Cvitanovic et al. } \\
\text { 2015, Nguyen et al. } \\
\text { 2016, Bednarek et al. } \\
\text { 2018, Fabian et al. } \\
\text { 2019, Pearce and } \\
\text { Evans, 2018, Chubb } \\
\text { and Watermeyer, } \\
\text { 2017; Smith and } \\
\text { Stewart, 2017 } \\
\text { Fazey et al., (2013) }\end{array}$ & $\begin{array}{l}\text { Our experience would suggest that recognition of the time and cost } \\
\text { required to successfully engage with knowledge users over a long } \\
\text { time period needs to be recognised in academic workload models } \\
\text { and moreover the additional administrative burden and associated } \\
\text { with involvement in extensive knowledge exchange activities needs } \\
\text { to be supported in the long term ( } 2+\text { years), where universities want } \\
\text { particular KE / impact activities to be developed. Research } \\
\text { intensive UK universities generally allow academic staff to } \\
\text { specialise in teaching or research - it may be worth considering } \\
\text { alternatively a specialisation in KE as equivalent to teaching or } \\
\text { research in terms of academic career progression. }\end{array}$ \\
\hline
\end{tabular}




\begin{tabular}{|c|c|c|c|}
\hline $\begin{array}{l}\text { 7. Addressing the } \\
\text { disparity in } \\
\text { timescale between } \\
\text { research delivery } \\
\text { and stakeholder } \\
\text { knowledge } \\
\text { requirements. }\end{array}$ & $\begin{array}{l}\text { Increase the uptake and effectiveness of environmental } \\
\text { research by delivering tangible results as soon as possible for } \\
\text { your stakeholders. }\end{array}$ & Reed et al. 2014 & $\begin{array}{l}\text { M-KEN generated a wealth of opportunities through its network } \\
\text { building and knowledge discovery activity. However, the disparity } \\
\text { between the timescale of research, or even of developing research } \\
\text { or knowledge exchange outputs from existing knowledge within the } \\
\text { academic environment, and the timescale of need from the } \\
\text { stakeholders was a particular challenge for realising some of these } \\
\text { opportunities. This was especially the case in the period of } \\
\text { operation prior to co-developing interdisciplinary research with } \\
\text { stakeholders, when M-KEN was brokering existing knowledge } \\
\text { from a portfolio of completed and ongoing research. The novel } \\
\text { infographics work }\end{array}$ \\
\hline
\end{tabular}




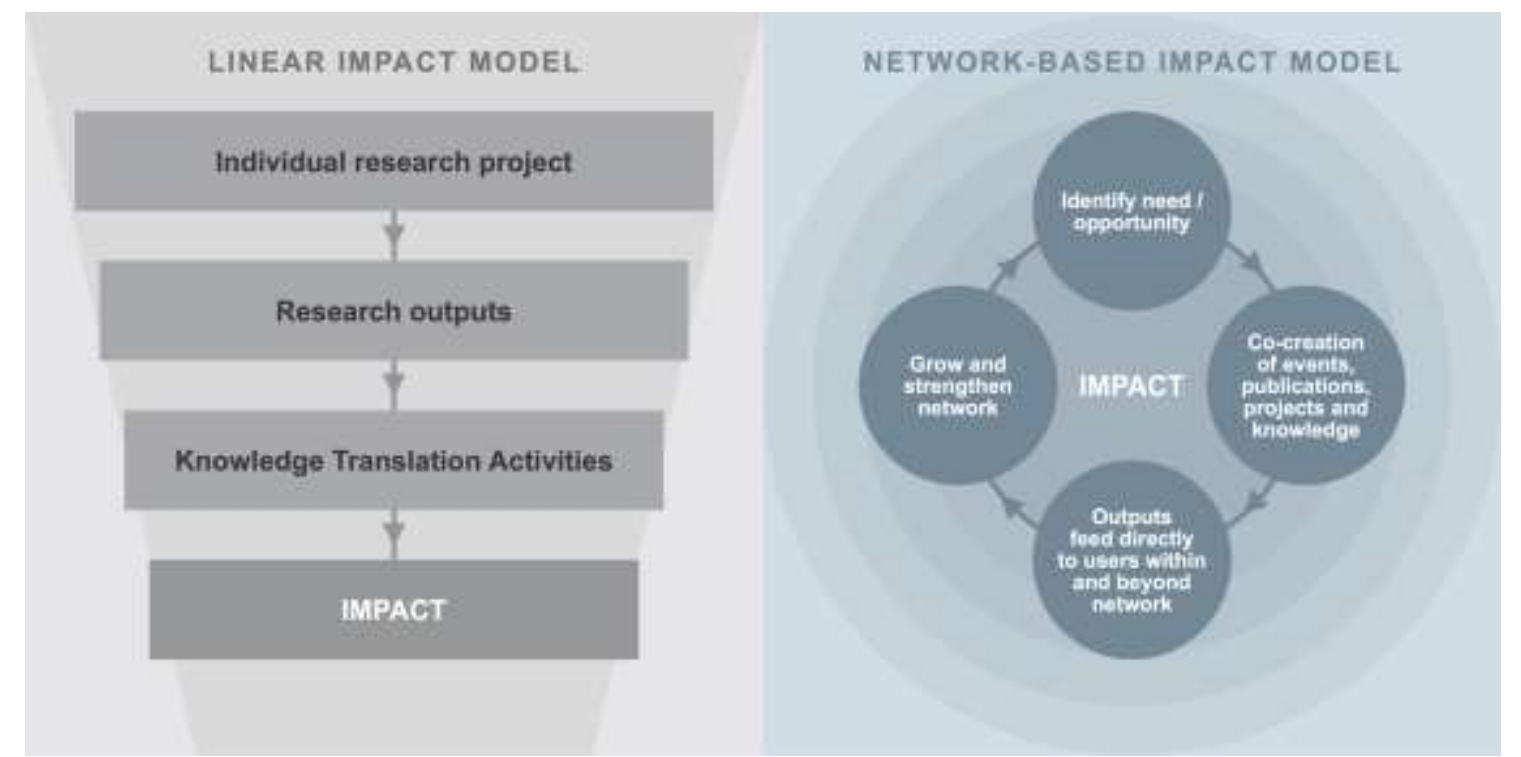

Fig 1. Traditional 'linear' model of impact generation on a per-project basis versus M-KEN's envisaged network-based impact 'cycle' for a portfolio of research. 


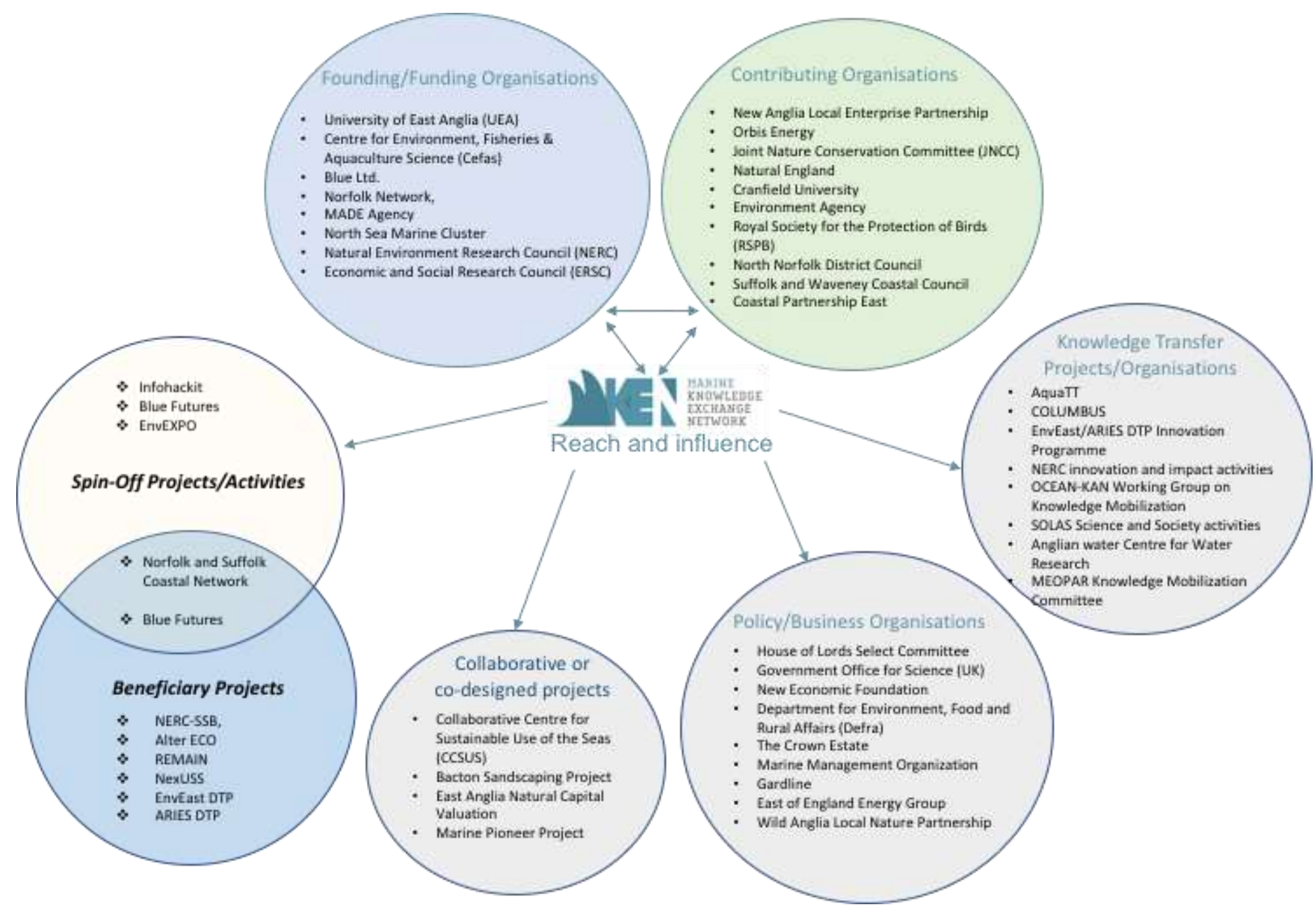

Figure 2. M-KEN's reach and influences on organisations, initiatives and other KE/impact activities. 


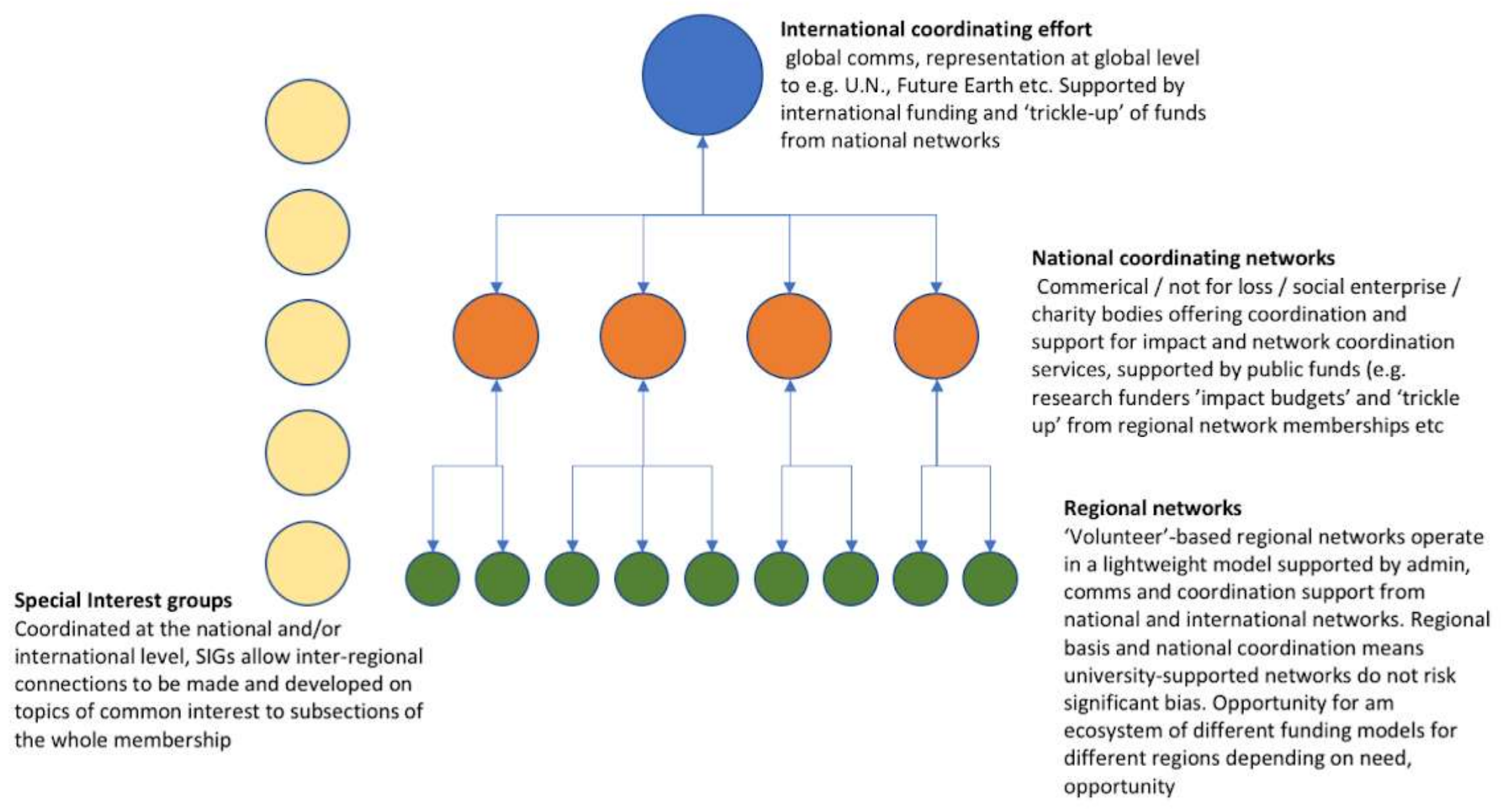

Figure 3. Potential structure of a future global Ocean-KEN 